\title{
The Role of the $I_{s}$ la $h$ Movement in the State's Constitution of Perlis, Malaysia
}

\author{
Mohd. Nasir bin Abd. Hamid \\ Centre for Islamic Thought and Understanding (CITU) \\ Universiti Teknologi MARA \\ 02600, Arau, Perlis, Malaysia
}

Tel: 60-3-017-477-1105 E-mail: mdnasir@perlis.uitm.edu.my

\author{
Che Latifah binti Ismail \\ Centre for Islamic Thought and Understanding (CITU) \\ Universiti Teknologi MARA \\ 02600, Arau, Perlis, Malaysia
}

Tel: 60-3-012-493-9913 E-mail: chelatifah@perlis.uitm.edu.my

Kamaruzaman Jusoff (Corresponding Author)
Faculty of Forestry
Universiti Putra Malaysia
43400 Serdang, Selangor, Malaysia

Tel: 60-3-8946-7176 E-mail: kamaruz@putra.upm.edu.my

\begin{abstract}
In $19^{\text {th }}$ Century CE the term is la $\bar{a} h$ is used to denote 'reform' to perceive idealism of reformers, al-Afgh $\overline{\mathrm{a}} \mathrm{n} \overline{\mathrm{i}}$, 'Abduh and Rida and those who were influenced by them. They struggled to refine Muslim society and to call them back to Islam. The objective of this paper is to study factors of diffusion of the idealism in Perlis, Malaysia. Besides, it would indicate the role of the is $l \bar{a} h$ movement in determining the notion of Perlis's Constitution. Through researches in many documents as well as interview $\underline{\underline{s}}$ the study found that the movement in Perlis emerged in the early 1920s CE to challenge the practice of the Sh $\bar{a} \mathrm{fi}^{\prime} \overline{\mathrm{i}}$ madhhab (school of thought) in the state. The movement succeeded in challenging the strength of Kaum Tua (the Shafi'i adherents) and caused the closing of their pondok (learning centre). What was more important, the movement's proposal to establish the doctrines of ahl al-sunnah wa-'l-jam $\bar{a}$ 'ah without being subject to any particular madhhab to be the basis of the State's structures gained the support of the Perlis Sovereign as well as the State Executive. Meanwhile, a King who would be appointed to govern the State should be a person who follows the doctrines. When compared with provisions of the other States in Malaysia it means that only Perlis has chosen to make an open rejection to the practice of taql $\bar{i} d$ of particular madhhab in the State's religious administration. Therefore, it would be good to suggest that people should be given a wide opportunity to study, to accept and to practise any opinion that is in accordance with al-Qur'a $n$ and al-Sunnah in order to show a great appreciation of the State's doctrine.
\end{abstract}

Keywords: Idealism of reformers, Factors of diffusion, Determining the notion, Sh $\overline{\mathrm{a}} \mathrm{fi} \cdot \overline{\mathrm{i}}$ madhhab

\section{Introduction}

In modern Arabic the term is $l \bar{a} h$ is used to denote 'reform' in a general sense. It is perceived as a function of the historico-cultural process in modern Islam, a modern form of the salafiyya. It refers more expressly to the group that emerged at the end of the 19th century in the doctrinal teachings of Jam $\bar{l} 1$ al-D $\overline{\mathrm{i}} \mathrm{n}$ al-Afgh $\mathrm{a} \overline{\mathrm{i}}$ (1254-1315 AH/1839-1897CE), Muh ammad 'Abduh (1266-1323AH/1849-1905CE) and in the writing of Muh ammad Rash $\overline{\mathrm{i}} \mathrm{d}$ $\operatorname{Rid}\{\mathrm{a}<(1282-1354 \mathrm{AH} / \mathrm{i} 865-1935 \mathrm{CE})$ as well as in the many Muslim authors who have been influenced by these masters. For example, 'Abd al-Qa<dir al-Maghribi (1284-1376AH/1867-1956CE) in Morocco and Shaykh Tahir 
Jalaluddin (1286-1377AH/1869-1957CE) in Malaysia who made a very fertile contribution to is $\bar{l} \bar{h}$ in the both countries. Those reformers struggled to refine Muslim society from superstition and call them back to the original teachings of Islam. They want people to think in term of getting ahead, to justify opinions as better or worse and to motivate themselves to utilize their natural surroundings (Donzel 1960. See also Britannica Encyclopedia 2007).

In order to fulfill these aims al-Afgh $\bar{a} \mathrm{n} \overline{\mathbf{i}}$ insisted that the success of the aim necessitated the abolition of taql $\bar{i} d$. (Note 1) He pointed out that the early ' ulam $\bar{a}$ ' exercised the right of independent judgement but they had not exhausted all the secrets of al-Qur'a $n$. Thus, a new ijtiha $d$ was required to solve new issues and even to revise the previous opinions, for the situation in that time did not conform to the current circumstances (Moazzam 1984). (Note 2) Meanwhile, "Abduh regarded taql $\bar{i} d$ as a disease which blinds the practitioners. In al-Man $\bar{a} r$, he blamed those who commanded people to practice taql $\bar{i} d$ without understanding and being satisfied with the view of the 'ulam $\bar{a}$ ' ("Abduh $\&$ Rashid 1952). 'Abduh argued that the principle of talf $i q$ (which implies that in any particular case one should choose the best interpretation of the law befitting the circumstances whether it comes from one's own legal code or not), should be practiced especially by jurists. (Note 3) In his view, talf $\bar{i} q$ was a systematic comparison of all four madh $\underline{\underline{a}}$ hib or even other jurists so as to get the best synthesis for the right judgement (Hourani 1962). Nevertheless, $\operatorname{Rash} \underline{\mathrm{i}} \mathrm{d} \operatorname{Rid}\{\mathrm{a}<$, in this matter presented his own stand by calling every Muslim to entertain the rules of all four madha hib, or to accept any procedure of the four which was convenient to him/her. He thought that was a better way to avoid the false innovations of ignorant men who deviated from Islamic teachings for their own glorification (Adams 1933). His concern was to minimize the questions of differences between Muslims so as to show Islam to be a religious of unity. Therefore, he proposed a greater freedom for everyone to support what they agree upon and be tolerant of differences (Badawi 1976. See also Sasi 1995).

\section{The wind of is $l \bar{a} h$ in Malaysia}

The wind of $i s \vec{a} h$ in the Middle-East blew across the ocean and caused the rising tide of is $l \bar{a} h$ in the Malay Archipelago, in this case, Indonesia and Malaysia. Students from this area who had studied in the Árabic countries brought back the spirit of al-Afghani and 'Abduh, as well as the teaching of Shaykh Muhammad bin 'Abd al-Wahhab from Saudi Arabia to become the stimulus in motivating a reform movement in their society. In Indonesia, the is $l \bar{a} h$ movement became aggressive in the early 19th Century CE when the three scholars Haji Miskin, Haji. Sumanik and Haji. Piobang, well-known as the Paderi group who had studied in the Middle-East, came back to Minangkabau, Sumatra (Othman \& Badaruddin 1991). They began to direct their attacks against the deterioration in the society and opposed some practices of the ' $\bar{a}$ dat ja hiliyyah in Minangkabau, for example; drinking tuak (an alcoholic drink) (Othman \& Badaruddin.1991). They also warned people about the intensive Dutch exploitation in Indonesia (Ricklefs 1984).

At the end of the 19th century CE many people in Indonesia thought that it was impossible to challenge the forces of Dutch colonialism or struggle for progress in other parts of Asia if they continued with their traditional activities to uphold Islam. They became aware of the need for changes or reforms by digging up the treasures of Islam of the past which had enabled their brethren of the Middle Ages to surpass the West (Noer 1973). In the meantime, some opponents of the Paderi movement who had escaped from the Dutch attacks had been looking for a new base to continue their struggle for reform (Othman \& Badaruddin 1991).

By the time, Shaykh Tahir Jalaluddin from Bukit Tinggi, Minangkabau who cameback from Middle-East in 1317 AH/1899 CE decided to chose Singapore (in that time, Singapore was the Malaya's constituency) as his field of operation for reform. As a best friend of Rashid Rida and the follower of 'Abduh he and some other friends who were the members of the urban Malayo-Muslim community of Singapore and had extensive contacts with the Middle East, such as Sayyid Shaykh Ahmad b. al-Hadi (1862-1934CE), Haji Abbas M. Taha (1885-1946CE) began to publish al-Imam, a periodical which used 'Abduh's nickname and followed the al-Mana $r$ model, in July 1324AH/1906CE, a year after 'Abduh's death (Noer 1973).

Al-Im $\bar{a} m$ was the first Malay radical publication formulating an intellectual stance in Malay society to build up religious awareness for fast social and economic change (Abdullah 1992). Its aims were "to remind those who are forgetful, arouse those who sleep, guide those who stray, and give a voice to those who speak with wisdom". In order to achieve these ideals it was firstly concerned with religion, "for religion is the proven cure for all the ills of our community" (Roff, 967). It warned the Malay people that the main cause of the decline of Muslim glory is their ignorance of their religion and inability to follow the commands of God and the Prophet (p.b.u.h). It indicated that a correct sympathy with and resignation to the direction of Islam is "our only means of competing successfully with those who now rule and lead us" (Roff 1967).

However, al-Imam reflected awareness that in order to achieve is $l \bar{a} h$, the practice of Islam among the Malays must be free from customs and beliefs derived from ' $\bar{a}$ dat, other religions and animism. So, in the article Tegoran (An Address), translated from the Arabic of 'Abduh, it reminded 'ulam $\bar{a}$ ' of their responsibiliy to preach the truth, and stress the need to return to al-Qur'a $n$ and al-Sunnah as well as to practice ijtiha $d$ rather than taql $\bar{i} d$ buta (blind 
acceptance of intermediate authority) in their approach to the modern world. Al-Imam called the authorities and the masses to work for the excellence and clarification of Islam, including an increase in social and economic development for the advancement of Malay society (Roff 1967).

The influence of the voice of reform spread significantly in the Peninsula of Malaya while in the early $1340 \mathrm{sAH} / 1920 \mathrm{sCE}$ the call for reform in Perlis began to develop. Consequently, the call to 'stop the culture of taql $\bar{i} d$ ' that was being expounded by the reformers had a big impact on the practices of the Shafi'i madhhab (school of thought) among the people of Perlis (Abdullah 1989).

\section{Is la $\bar{h}$ in Perlis}

Perlis, in full Perlis Darul Sunnah, is the smallest state in Malaysia. It lies at the northern part of the west coast of Peninsular Malaysia and has Satun and Songkhla Provinces of Thailand on its northern border. Perlis has a population of 210,000. The ethnic composition for the year 2000 in Perlis was: Malay (174,805 or 79.74\%), Chinese (21,058 or $9.6 \%)$, Indian $(2,658$ or $1.21 \%)$ and others $(20,690$ or $9.45 \%)$. The capital of Perlis is Kangar and the royal capital is Arau. Since 2000, the Raja or hereditary monarch has been Tuanku Syed Sirajuddin Putra Jamalullail (http://en.wikipedia.org/wiki/Perlis).

Over the centuries the Sh $\overline{\mathrm{a}}$ fi ${ }^{\circ} \overline{\mathrm{i}}$ madhhab had become dominant in South-East Asia. The preachers who came to the Malay Peninsula either from Hadramaut, Yemen or other parts of Middle-East being considered under the influenced of the Sh $\overline{\mathrm{a}} \mathrm{fi} \times \overline{\mathrm{i}}$ madhhab in their preaching as well as in their interpretation of jurisprudence. Consequently, the Malay people became followers of that madhhab. Considering the development of the madhhab through education and law in Malaysia, most states in Malaysia - Kelantan, Kedah, Perak, Pulau Pinang, Trengganu, Negeri Sembilan, Melaka, Selangor and Johore accepted the $\mathrm{Sh} \overline{\mathrm{a}} \mathrm{fi}^{\circ} \overline{\mathrm{i}}$ madhhab and its fat $\bar{a} w \bar{a}$ and application of Islamic Law (el-Muhammady 1982). In Perlis, it was also a dominant movement and had supporters among the leadership and noblemen of the state. Many religious leaders were those from the madhhab such as Haji Muhammad. Noor b. Haji Muhammad, the ex-Muft $\bar{i}$ of Perlis from 1339-1360AH/1920-1941CE (Abdullah 1989).

However, in the early $1920 \mathrm{sCE}$ some 'ulam $\bar{a}$ ' who previously had not dared to challenge the teaching and practice of the Sh $\overline{\mathrm{a}} \mathrm{fi}$ ' $\overline{\mathrm{i}}$ madhhab in the state began to do so. Among them were Lebai Kecik from Indonesia (who stayed in Batu Lima, Jalan Kuala Perlis), Pakih Sidin, Sayyid Ibra h i m from Hadramaut (Zam-zam 1986). Another one was Haji Mohd. Rawi (1318-1372AH/1900-1952CE), who was born in Sumatra and educated in Makkah for ten years. After which he moved to Perlis and opened a school, the Madrasah Khairiyyah, in 1356AH/1937CE. Among the student of the school was Haji Abdul Rahman Haji Isma'il, the former Mufti of Perlis from 1391-1403AH/1971-1982CE (Abdullah 1989). Although those 'ulam $\bar{a}$ ' were not given a tumultous welcome by the masses many learnt about Islam from them and they can be considered to have laid the foundation for is $l \bar{a} h$ in Perlis (Zam-zam 1986).

However, the most important man was a local scholar, Haji Ahmad b. Haji Muhammad (1303-1384AH/1885-1964CE), who was educated at Makkah and worked as a State Chief Justice and also the first Chairman of the Majlis Ugama Islam dan 'Adat Isti'adat Melayu (The Council of Islamic Religious and Malay Customs), from 1368-1380AH/1948-1960CE. (Note 4) He was well-known as Haji Ahmad Hakim and was elected as one of the members of Jemaah Pemangku Raja (The Council of Succession of the King) on occasions when His Majesty visited other countries. He reorganised the way of collecting zakat and fit\}rah in 1345AH/1927CE (Othman \& Badaruddin 1991). (Note 5) For the first time, only those appointed 'ummal_(collectors of zakat and fit'sah) were permitted to collect zakat and fit\}rah. This rule was a threat to some 'ulama' from Kaum Tua (old faction, the adherent of the $\mathrm{Sh} \overline{\mathrm{a}} \mathrm{fi} \cdot \overline{\mathrm{i}}$ ) who depended on the sources for the survival of their pondok (traditional learning centre). Although they were against the proposal, the King, Raja Syed Alwi (1323-1363AH/1905-1943CE), legalized it and then a committee was set up in $1351 \mathrm{AH} / 1933$ CE namely Jawatankuasa Perusahaan (The Committee of Industry) to manage the regulations (Abdullah,1989). Eventually, according to Mat Jahya (2002), the former Mufti of Perlis, in 1940sCE many pondoks in Perlis were closed such as Pondok Haji M. Rejab in Beseri, Pondok Haji Ishak in Mata Air, Pondok Haji Rawi in Santan and some others. This means that the strong base of Kaum Tua to challenge the idea of is la $h$ had been weakened significantly. Two more persons who made a serious contribution to the spread of the idea of $i \dot{s} l \bar{a} h$ were Wan Ahmad b. Wan Daud (1310-1390AH/1892-1970CE) and Shaykh Ahmad b. Mohd. Hashim. Wan Ahmad b. Wan Daud worked as a Confidential Secretary to the King of Perlis and was appointed the Speaker of the State Common House in May, 21th $1959 \mathrm{CE} / 1379 \mathrm{AH}$. He visited Indonesia to learn about Islam and the reform movement there. Shaykh Ahmad b. Mohd. Hashim (1314-1401AH/1896-1980CE), was appointed the Perlis Chief Minister in May, 28th 1959CE/1379 AH until December, 31th 1971CE/1391AH after he won the state election. Haji Ahmad b. Haji Mohammad, Haji Ahmad b. Wan Daud and Shaykh Ahmad b. Mohd. Hashim are well-known as Tiga Mad (The Three Ahmads), and they were members of the Jawatankuasa Perusahaan which made an important contribution in introducing reform in Perlis. They brought in many books and magazines as well as the publications that contained ideas about reform. Through these media people could read more about the opinion of reformers and consequently, 
according to Ahmad (2002), the adviser of the movement, the struggle of the $i s \underline{\bar{a}} h$ gained more supporters and sympathizers (Abdullah 1989).

What was more encouraging for them was a visit by Shaykh Hassan, an ' $\bar{a}$ lim from Saudi Arabia to Perlis in $1345 \mathrm{AH} / 1927 \mathrm{CE}$ who strongly supported the movement. By this time, many state leaders and noblemen were attracted by the success of the Wahhab $i$ movement in the country. (Note 6) They were looking for a good example to copy in Perlis. Thus, Shaykh Hassan gave priority to teaching the masses and to call them back to al-Qur'a $n$ and al-Sunnah and throw away all khurafat and bid'ah (deviation). Wan Ahmad Wan Daud writing in his diary, about Shaykh Hasan's visit to Perlis claims that the movement went from strength to strength and progressed to champion reform programmes together with reformers in the holy land in combating all deviation (Din 1981)

\section{The period of glory}

During the Japanese period in Malaya (1360-1365AH/1941-1945CE) the political situation in Perlis was in trouble and the activities of is la $h$ were significantly curtailed. In 1365AH/1945CE the Japanese were defeated and British came back to Malaya and confirmed Syed Putra Jamalullail as the King of Perlis in December 4th 1945CE/1365AH. His Majesty raised no objection to welcoming back the reformers. He supported their activities "as long as there was no bloodshed". No doubt, it was a great time for them. In addition the Tiga Mad were appointed as Ahli Majlis Negeri (Members of the State Council). Furthermore, when the Majlis Ugama Islam dan 'Adat Isti' 'adat Melayu Perlis was established in 1368AH/1948CE, Haji Ahmad Hakim was appointed the first President and also the Chairman of the Department of zakat and fit\}rah, while Wan Ahmad was assigned as the accountant and Shaykh Ahmad as the Secretary of the department (Abd. Hamid 1996).

In addition, many state officials showed their support for the Tiga Mad. Therefore, they easily organized many programmes, such as founding religious classes, and selected imams and religious teachers etc. in order to fulfill the objectives of is la h (Othman \& Badaruddin 1991). A new post, namely a Religious Inspector was created to inspect and report the performance of religious duties in Perlis to the Chairman of the Majlis Ugama Islam dan 'Adat Isti'adat Melayu. Consequently, the Majlis could monitor religious activities and would take action about any activity that opposed the Majlis's policy as well as controlling the influence of the Sh $\bar{a}$ fi $\overline{\mathrm{i}}$ madhhab in Perlis. As a result, the influence of is la $h$ became stronger and more powerful (Abdullah 1989).

\section{Determining the notion of the state's constitution}

Leaders of the movement who held the top posts of the State Government seemed to believe that Perlis was the only one among the States in Malaysia which had a good reputation and respected the struggle for reform. They saw it as the potential basis for the movement's ideals, i.e. that it would be a place where al-Qur'a $n$ and al-Sunnah would be the basis of reference without taqli $d$ or dependence on any particular madhhab in fiqh. They considered that the role of the movement in Perlis should be supported continuously by the State authority in order to make it an effective one to fight the culture of taql $\bar{i} d$ of the Sh a fi ${ }^{\circ} \bar{i}$ madhhab in most States in Malaysia. This was something they thought had to be done immediately while the movement was seen as the champion of reform and was appreciated by the people of Perlis.

Therefore, on 26th March 1959 CE/1379 AH leaders of the movement proposed to the Perlis Sovereign and the State's Executive that the doctrines of the ahl al-sunnah wa-'l-jama' 'ah (the people of sunna and of the community), should be established as the basis of the State's structures. The term, according to the movement's authority refers to those who follow the doctrines of al-Qur'a $n$ and al-Sunnah without being subject to any particular school of thought in fiqh (Abdullah 1989). For this purpose, a King who would be appointed to govern the State of Perlis should be a person who practises Islam and follows the doctrines of ahl al-sunnah wa-'l-jam a 'ah. This proposal gained the support of the State Executive and thus, article 19 of the Laws of the Constitution of the State of Perlis established that "The Sovereign shall be a person who is a Malay, of Royal blood, a descendant of the Perlis Sovereigns, a male and of the Muslim Religion Ahli Sunnah Waljamaah" (The Laws of the Constitution of the State of Perlis 1959).

In order to exercise His functions as Ruler, the Sovereign has to appoint a Regent or Council of Regency, as seems most expedient to Him, but no person shall be "appointed as Regent or as a member of the Regency unless he is a Malay, professing the Muslim Religion Ahli Sunnah Waljamaah" (The Laws of the Constitution of the State of Perlis 1959).

Later, steps were taken to authorise the doctrines in the State's religious administration. The meaning of the doctrines, according to the movement's point of view, needed to be stated clearly; that is, al-Qur' $\bar{a} n$ and al-Sunnah should be established in the State's Regulation as the basic point of reference without mention of any particular madhhab. The movement believed that it would be much better for the religious authorities to practise ijtiha $d$ as well as to choose any fatw $\bar{a}$ which was strongly supported in the revelation and was more appropriate to the current conditions. In this way, the establishment would give strength to the struggle of the movement in the future. Therefore, in $1383 \mathrm{AH} / 1963 \mathrm{CE}$ a new article was introduced in the Undang-Undang Pentadbiran Ugama Islam Perlis (The Laws of the Perlis Islamic Administration), and Part 2, article 7 (4) of the Laws confirmed that "The Majlis when issuing a Fetua and the Shari'ah 
Committee when giving its opinion under sub-section (2) shall follow the al-Qur'an and or Sunnah Rasulal Allah Alaihi Wasallam" (Ishak 1985).

This is different to some other States' Constitutions in Malaysia that follow a certain madhhab. For instance, The Laws of the Constitution of Perak - Part 11, Article 5 clearly states in the 'Qualification of Sovereign' that "The Sovereign shall be a male who is a Malay of Royal blood through male lineal descent, able to read and write and professing the Muslim Religion of the Shafi 'i Muzahab” (Abd. Hamid 1996).

The above statements provided that in 'making and issuing a ruling' the Majlis and the Shar $\bar{i}$ 'ah Committee shall ordinarily follow the most approved juristic view (al-qawl al-mu'tamad, mistakenly rendered in the Enactments as 'orthodox tenets') of the Sha fi' $\overline{\mathrm{i}}$ madhhab (rendered as a 'sect' in the Enactments), but where the public interest (al-mas lah a al- ' $\mathrm{a}$ mmah) so require the fatwa may be given according to the tenets of the other schools, but only with the special sanction of the Sovereign (Ishak 1985). However, the provisions of the Perlis Administration of Muslim Law Enactment (1964), alone of all such Enactments on the subject states simply that the Majlis and the Shar $\bar{i}$ 'ah Committee 'shall follow the Qur'a $n$ and the Sunnah of the Prophet (p.b.u.h), omitting all reference to any of the established schools of Islamic law or the need to adhere to any of them (Ibrahim et.al.,1985)

\section{Conclusion}

Local scholars believe that the phenomenon in Perlis seems to be a great achievement of the $i s \bar{l} h$ movement and shows a great appreciation for its reformers. Officially, Perlis has refused to practice taql $\bar{i} d$ of only one madhhab but it might be true that people are given a wide opportunity to accept and to practise any opinion that is in accordance with al-Qur'an and al-Sunnah. This is an innovation of unimaginable magnitude when compared with provisions of the other States in Malaysia. It means that at least one state - Perlis has chosen to disregard - perhaps in a bid to stimulate a measure of creativity - the partisan tendencies in the historical development of Islamic legal thought by the open rejection of the doctrine of taql $\bar{i} d$.

\section{References}

Abduh, al-Shaykh Muhammad, and Rida, Rashid, al-Sayyid Muhammad. (1372/1952). Tafsir al-Qur'an al-Karim al-Shahir bi 'l-Tafsir al-Manar, vol. 2 (12 vols.). Cairo: Maktabah al-Qahirah.

Abdullah H., Abdul Rahman. (1989). Gerakan Islah di Perlis - Sejarah dan Pemikiran. Kuala Lumpur: Dewan Bahasa dan Pustaka.

Abdullah H., Abdul Rahman. (1992). Pemikiran Islam Masa Kini - Sejarah dan Aliran. Kuala Lumpur: Dewan Bahasa dan Pustaka.

Abd. Hamid, Mohd. Nasir. (1996). Islamic Reform (Is la $h$ ) with Special Reference to the $I S l \bar{a} h$ Movement in the State of Perlis Malaysia. A Thesis submitted to the Faculty of Arts of the University of Birmingham, U.K. for the Degree of M.Phil.

Adams, C., Charles. (1933). Islam and Modernism in Egypt - A Study of Inaugurated by Muhammad 'Abduh. Oxford: Oxford University Press.

Ahmad Yusuf Amin. (2002). The struggle of islah in Perlis. Interview, $13^{\text {th }}$ March.

Al-'Alwani, Taha J. (1992). 'Taqlid and Ijtihad'. In The American Journal of Islamic Social Sciences, vol. 9, no. 2, p. 233.

Al-'Alwani, Taha J. (1992). 'The Crisis of Thought and Ijtihad'. In The American Journal of Islamic Social Sciences, vol. 9 , no. 2, p. 237

Badawi, Zaki, M.A. (1976). The Reformers of Egypt. London: Open Press.

Britannica Encyclopedia. (2007). Jamal al-Din al-Afghani. Online Edition.

Din, Harun. (1981). Sejauhmanakah Perbezaan Amalan Keislaman yang Terdapat di Negeri Perlis yang Tidak Bermazhab dengan Negeri-negeri yang Bermazhab Shafie di Malaysia. Bangi: A research to the Faculty of Islamic Study, UKM.

Donzel, E. Van, Lewis, B. and Pellat, Ch. (Eds.) (1960). The Encyclopaedia of Islam, the new edition, Leiden: E.J. Brill.

El-Muhammady, Abdul Halim. (1982). The Influence of Shafi'ite School of The Muslim Law in Malaysia. Bangi: Faculty of Law, UKM.

Gibb, H.A.R. and Krames, J.H. (Eds.). Shorter Encyclopaedia of Islam. Leiden: E.J. Brill.

Glasse, C. (1989). The Concise Encyclopaedia of Islam. New York: Stacey International. 
Hassan, Kamal M. (1994). Islamic Intellectual Life in the Malay-Indonesian Archipelago: A Preliminary Observation. The Paper presented in a Seminar on Islam at Selly Oak Colleges in December 7th.

Hourani, Albert. (1962). Arabic Thought in the Liberal Age 1798-1939. Oxford: Oxford University Press.

Ibrahim, Ahmad. (1965). Islamic Law in Malaya. Kuala Lumpur: Malaysian Sociological Research Institute Ltd.

Ibrahim, Ahmad \& Siddique, Sharon \& Hussain, Yasmin (Eds.). (1985). Readings on Islam in Southeast Asia. Singapore: Institute of Southeast Asian Studies.

Ishak, Othman. (1971). The Relationship Between Islamic Law and Customary Practices in Newly-Islamized Societies, With Special Reference to the Law of Succession in Malaya. M. Phil. Thesis, University of Birmingham.

Ishak, Othman . (1985). Talfiq Dalam Perundangan Islam. in Lutpi Ibrahim, Mohammad Abu Bakar, Mohd. Nor Ngah, Engku Ibrahim Engku Ismail \& Mahfodz Mohamed (Eds.), ISLAMIKA 111, p. 95. Kuala Lumpur: UM.

Mat Jahya b. Husin. (2002). The History of pondok in Perlis. Interview, $1^{\text {st }}$. September.

Moazzam, Anwar. 1984. Jamal al-Din al-Afghani - A Muslim Intellectual. New Delhi: Concept Publishing Company.

Noer, Deliar. (1973). The Modernist Muslim Movement in Indonesia, 1900-1942. Oxford: Oxford University Press.

Othman H., Mohd. Radzi \& Baharuddin Dato', O.K. Rahmat. (1991). Gerakan Pembaharuan Islam di Negeri Perlis dan Kaitannya dengan Gerakan Pembaharuan Islam di Negeri-negeri Lain di Dalam Malaysia. A Research to the University of Science, Malaysia.

Ricklefs,M.C. (1984). Islamization in Java - An Overview and Some Philosophical Consideration. In Israeli, Raphael \& John, H., Anthony (Eds.). Islam in Asia, Volume 11, South-East \& East Asia. The Hebrew University of Jerusalem: The Magnes Press.

Roff, William R. (1967). The Origin of Malay Nationalism. Yale: Yale University Press.

Sasi, Louay. 1995. From Reform to Revolution. Intellectual Discourse, vol. 3, No. 1, pp 23-49.

Seferta, H.R., Yusuf. (1994). The Concept of Religious Authority According to Tafs $\bar{i} r$ al-Man $\bar{a} r$ and Other Writing of Muhammad 'Abduh and Rashid Rida, and Its Bearing upon Their Critique of Christianity and Judaism. A Ph.D thesis to the Department of Theology, University of Birmingham.

The Laws of the Constitution of Perlis. (1959).

Zam-zam, Zainal Abidin. (1986). Sunnah, Mazhab dan Perkembangannya. A paper presented in the ijtima' al-Sunnah in Perlis on 30 J'Awwal-1 J'Akhir 1406/ 9-10th February.

Notes

Note 1. As a term of fiqh (Islamic jurisprudence), the classical fuqah $\bar{a}$ ' (Islamic jurists) define taql $\bar{i} d$ as "one's acceptance of another's opinion madhhab without knowing the other person's justification or trying to substantiate it" (Al-‘Alwani 1992).

Note 2. According to the classical doctrine of Islamic legal theory, ijtih $\bar{a} d$ means exerting oneself to form an opinion (zann) in a case or as to a rule of law. This is done by applying analogy (qiy $\bar{a} s$ ) to al-Qur' $\bar{a} n$ and al-Sunnah (Donzel 1960). According to al-'Alw $\overline{\mathrm{a}} \mathrm{n} \overline{\mathrm{i}}$, al-Ghaz $\overline{\mathrm{a}} \mathrm{l} \overline{\mathrm{i}}$ defined ijtih $\bar{a} d$ as, "The expending, on the part of a mujtahid (the lawyer who is qualified to use it), of all what he/she is capable of in order to seek knowledge of the Shar $\bar{i}$ 'ah injunctions. Complete ijtih $\bar{a} d$ happens when the mujtahid expends all of his/her energies in seeking, to a point where he/she is satisfied that no more can be done". This definition refers to ijtih $\bar{a} d$ in the field of law and indicates that the effort expanded must be exhaustive and emanate from those who are qualified. If an unqualified person undertakes these same efforts, one cannot say that ijtih $\bar{a} d$ has been performed (al-'Alwani 1992). 
Note 3. Talf $\bar{i} q$ means, "in any particular case one should choose the best interpretation of the law befitting the circumstances whether it comes from one's own legal code or not" (Abduh and Rida 1372/1952).

Note 4. The Government of every State in Malaysia established a seperate body commonly known as the Majlis Ugama Islam dan Adat Isti'adat Melayu in order to solve the ongoing questions and to reconcile the friction between the authority of the custom and the Islamic law. Although the regulation of the assignment and the authority of each council may be different from one State to another, generally the main duty of the Majlis is to help and advise the ruler of each State on all subjects relating to the Religious Administration, as well as to the Malay Custom. In Perlis the Majlis functioning at this time was established in 1368AH/1948CE and it was reorganized in 1384AH/1964CE under Part II of the Laws of the Constitution of Perlis (Amendment) 1383AH/1963CE. Members of the Majlis are elected by His Majesty, the King of Perlis (Ishak. 1971).

Note 5. Zakat; the alms-tax, one of the principal obligations of Islam. Fitrah; (zakat of the breaking of the fast) is the obligatory gift of provisions at the end of the month of Ramadan (Gibb and Krames (Eds.) 1974.

Note 6. Wahhabis; A sect dominant in Saudi Arabia and Qatar, at the beginning of the 19th Century it gained footholds in India, Africa and elsewhere. Adherents of this sect named after its founder Muhammad ibn 'Abd al-Wahhab (1115-1201 AH/1703-1787 CE), prefer to call themselves Muwahhidun (Unitarians) (Glasse 1989). 